University of Nebraska - Lincoln

DigitalCommons@University of Nebraska - Lincoln

\title{
$4-2013$
}

\section{The effect of gender quota laws on the election of women: Lessons from Niger}

\author{
Alice Kang \\ University of Nebraska - Lincoln, akang2@unl.edu
}

Follow this and additional works at: https://digitalcommons.unl.edu/poliscifacpub

Kang, Alice, "The effect of gender quota laws on the election of women: Lessons from Niger" (2013). Faculty Publications: Political Science. 56.

https://digitalcommons.unl.edu/poliscifacpub/56

This Article is brought to you for free and open access by the Political Science, Department of at DigitalCommons@University of Nebraska - Lincoln. It has been accepted for inclusion in Faculty Publications: Political Science by an authorized administrator of DigitalCommons@University of Nebraska - Lincoln. 
Published in Women's Studies International Forum 41:2 (November-December 2013), pp. 94-102;

doi: 10.1016/j.wsif.2013.03.005 Special issue on "Democratization and gender quotas in Africa"

Copyright $@ 2013$ Elsevier Ltd. Used by permission.

Published online April 16, 2013.

\title{
The effect of gender quota laws on the election of women: Lessons from Niger
}

\author{
Alice Kang \\ Department of Political Science, Institute for Ethnic Studies, University of Nebraska-Lincoln \\ 511 Oldfather Hall, Lincoln, NE 68588 USA; email akang2@unl.edu
}

\begin{abstract}
Between 2000 and 2012, ten African countries adopted candidate gender quota laws to improve women's descriptive representation in national legislatures. The effect of these laws on the election of women has varied widely. This article examines the effect of a gender quota law on the election of women as well as the appointment of women to the cabinet in the Republic of Niger to better understand the realities of applying legal gender quotas in Africa. It finds that the effect of the gender quota law on the election and appointment of women hinged on a combination of three factors: the design of the law, the institutional context, and the agency of women's activists who monitored the quota's implementation. In a democratizing context, women's activists used the Constitutional Court and the media to ensure respect for the quota law.
\end{abstract}

\section{Introduction}

When the door to multiparty elections opened in Africa in the early 1990s, the proportion of women in national legislatures experienced an unexpected setback. Women in 31 African countries occupied an average of $9.2 \%$ of seats in parliament before multiparty elections were organized. After the wave of multiparty elections, the average declined to $7.8 \%$ (Yoon, 2001, p. 176). Partly as a response to this decline, women's activists in and outside political parties advocated for the adoption of gender quotas to increase the presence of women in formal political life. In recent years, African countries have adopted a distinctive form of legislation to improve the balance of men and women in the national legislature and other political arenas. This legislation is known as national candidate gender quota laws, "constitutional provisions or national laws that require all political parties participating in legislative elections to include women on party ballots" (Schwindt-Bayer, 2009, p. 6). As of 2012, ten African countries have adopted gender quota laws to increase the percentage of women in the national legislature.

The effect of gender quota laws on the election of women in multiparty elections has been variable. In some countries, the difference in the percentage of women in the national legislature before and after the adoption of quota laws has been imperceptible. In others, the pres- ence of women jumped more than 20 percentage points. Scholars of women and politics have examined the variable impact of voluntary party quotas and reserved seats on the election of women in Africa (e.g., Ballington, 2004; Bauer and Britton, 2006; Yoon, 2001, 2013), particularly in countries ruled by autocratic and hybrid regimes (e.g., Goetz, 2003; Longman, 2006; Burnet, 2008, 2011; Muriaas and Wang, 2012; see also Tønnessen and Al Naggar, 2013; Wang, 2013). Others have argued that the use of quotas in places where democratic institutions and human rights are weakly protected will not promote democracy or equality (Hassim, 2010). Given their relative newness on the continent, however, little is known about the impact of gender quota laws on how women fare in elections in Africa.

This article examines the effect of a gender quota law on the election of women in a new democracy, the Republic of Niger. ${ }^{1}$ As one of the first African countries to adopt a gender quota law, Niger allows us to see the effects of a gender quota law over multiple election cycles. Niger's gender quota additionally sets a minimum requirement for the appointment of women and men to the executive cabinet and high-level positions in public administration. This duality of the gender quota law helps provide analytic leverage on why the effect of gender quota laws varies. As a new democracy, Niger also provides a valuable glimpse into the ways democratization and gender quota laws intersect. 
Niger's gender quota law increased the presence of women in national elected office from $1.2 \%$ in 1999 to $12.4 \%$ in 2004 . The quota law also resulted in an increase in the presence of women in the executive cabinet and other government bodies. I find that three factors helped shape the quota's impact: the design of the quota, the institutional context, and women's mobilization in and outside the political parties. First, I sketch out the different effects of candidate quota laws on the election of women to national legislature in Africa. Second, I identify prevailing explanations for why gender quotas vary in their effects on the election of women. Third, I explain Niger's quota system. Fourth, I examine the effect of Niger's gender quota law on the election of women in light of existing explanations. I conclude by reflecting on the complex interplay between democratization and gender quotas in Africa.

\section{Gender quota laws and the election of women in Africa}

Globally, gender quota laws are the most recent of gender quota innovations, newer than voluntary party quotas and reserved seat quotas (Krook, 2008). This is the case in Africa. In the late 1970s, authoritarian Egypt and Sudan were at the vanguard among African countries by adopting reserved seats for women (Howard-Merriam, 1990). Relatively democratic countries, in contrast, shied away from adopting reserved seat quotas. Instead, the most common type of gender quotas among democracies and democratizing countries were voluntarily adopted party quotas, which became widespread in Africa in the 1990s (Tripp, Casimiro, Kwesiga, \& Mungwa, 2009, pp. 153-7). Gender quota laws started to be adopted later in Africa, in the early 2000s.

As of 2012, ten African countries have adopted a gender quota law for national legislative elections. Half can be categorized as democracies in the 2000s and early 2010s. Niger and Senegal were considered democracies according to one measure (Cheibub, Gandhi, \& Vreeland, 2010). ${ }^{2}$ Burundi was an authoritarian regime and then became classified as a democracy in 2005. Libya and Tunisia were autocracies in the 2000s but witnessed the fall of long-standing autocratic rule in 2011 and 2012. The remaining five countries were categorized as autocracies in all or for most years during the 2000s - Algeria, Angola, Burkina Faso, Djibouti, and Mauritania.

The percentage of women elected to national legislatures (unicameral or lower-house) varies widely among African countries with gender quota laws (Table 1). In Algeria, Angola, Burundi, and Senegal, women constituted 30\% or more of the national legislature following the adoption of the gender quota law. By contrast, women made up less than $17 \%$ of the national legislature in Burkina Faso, Djibouti, and Niger, though women's presence did experience a boost of 4 to 11 percentage points.

It is difficult to draw a straight line from democratization to the election of women among countries with gender quota laws. Autocracies and democratizing countries saw significant increases in the presence of women in national legislatures following the adoption of gender quota legislation. Further, not all democratizing countries with quota provisions made significant gains, as was the case in Niger.
Table 1. Gender quota laws for the election of unicameral or lowerhouse legislatures in Africa.

\begin{tabular}{lllll}
\hline Country & Year & \multicolumn{2}{l}{ Women elected } & \multicolumn{2}{l}{ Women elected } \\
& adopted & before (year) & after (year) & Difference \\
\hline Angola & 2005 & $9.5 \%(1992)$ & $37.3 \%(2008)$ & $+27.8 \%$ \\
Senegal & 2010 & $18.0 \%(2007)$ & $42.7 \%(2012)$ & $+24.7 \%$ \\
Algeria & 2012 & $7.7 \%(2009)$ & $31.6 \%(2012)$ & $+23.9 \%$ \\
Burundi & 2005 & $9.9 \%(1993)$ & $30.5 \%(2005)$ & $+20.6 \%$ \\
Mauritania & 2006 & $3.7 \%(2001)$ & $17.9 \%(2006)$ & $+14.2 \%$ \\
Niger & 2002 & $1.2 \%(1999)$ & $12.4 \%(2004)$ & $+11.2 \%$ \\
Djibouti & 2002 & $0.0 \%(1997)$ & $10.8 \%(2003)$ & $+10.8 \%$ \\
Burkina Faso & 2009 & $11.7 \%(2007)$ & $15.8 \%(2012)$ & $+4.0 \%$ \\
Tunisia & 2011 & $27.6 \%(2009)$ & $26.3 \%(2011)$ & $-1.3 \%$ \\
Libya & 2012 & NA & $16.5 \%(2012)$ & NA \\
\hline
\end{tabular}

Liberia's gender quota only applied to the 2005 elections.

Sources: International IDEA (2012) and IPU (2012).

\section{Explaining the effect of gender quota laws on the election of women}

Why does the effect of gender quota laws on the election of women vary? According to the existing literature, a combination of three factors is important: quota design, national institutions, and the agency of actors.

\section{Quota design}

Scholars agree that the way a quota law is written influences the election of women. The higher the quota's minimum threshold, the bigger the impact it has on the election of women, even when controlling for other design aspects of the quota law (Schwindt-Bayer, 2009). If no minimum percentage is specified in the quota law, the law is less effective in increasing women's descriptive representation (Jones, 2004). Further, some quota laws include a placement mandate while others do not. This is pertinent in closed-list proportional representation systems where the electorate votes for a party's list of candidates and the parties rank the candidates. A placement mandate stipulates that parties place women in winnable positions on the party list. Some placement mandates specify that every other name on a list must be a woman. Others require that for every two men on a list, the third person must be a woman. When parties assemble their list of candidates in the absence of a placement mandate, they tend to place women at the bottom of the list or in less winnable seats, as has been found in France's national elections (Murray, 2004, 2010). The proportion of women in France's National Assembly, as a result, only increased to $12.2 \%$ in 2002 from $10.9 \%$ in 1997 (Krook, Lovenduski, \& Squires, 2009, p. 796). It has been noted, however, that female candidates can do well in the absence of placement mandates, such as in Peru's municipal elections (Schmidt \& Saunders, 2004).

Another significant element of quota design is the establishment of an enforcement mechanism. Without punishment for non-compliers, gender quota laws are "a mere recommendation" (Baldez, 2004; Dahlerup, 2006; Dahlerup and Freidenvall, 2005, 2011, Htun and Jones, 2002; Jones, 1996; Miguel, 2008; Schwindt-Bayer, 2009). The strongest enforcement mechanisms require that an independent au- 
thority examine and reject offending party lists. Weak enforcement mechanisms, in contrast, are a slap on the wrist. For instance, minor financial penalties are relatively easy for large parties to pay. Financial penalties in France did not deter parties from violating the quota law in 2002 as parties could afford to pay the fine. France restructured its financial penalty system in its revised quota law in 2007 and saw a modest improvement in the election of women; President Hollande further pledged to enhance enforcement by removing all party funding for parties that do not respect the quota (Murray, 2013, p. 198).

The total package of the gender quota can have a powerful effect on the election of women. In a global study of gender quota laws, Leslie Schwindt-Bayer (2009, p. 19) finds that if a $30 \%$ quota has a placement mandate and strong enforcement mechanisms, women make up $27 \%$ of the national legislature, on average. If a $30 \%$ quota, however, does not have a placement mandate and no enforcement mechanisms, then women make up $10 \%$ of the national legislature, on average.

\section{Institutional context}

Scholars also agree that pre-existing institutions - rules, norms, practices, and organizations that create or enforce rules - facilitate, or impede, the effect of gender quota laws on the election of women. The rules governing the conduct of elections are particularly relevant. Some suggest that quota laws are more likely to be effective in increasing women's presence in proportional representation electoral systems than in majoritarian systems (Matland, 2006). Among proportional representation systems, quotas are believed to have a greater impact in closed-list systems than in open-list systems (Gray, 2003; Htun and Jones, 2002; Jones, 2009; Jones and Navia, 1999). This is because in open-list systems, female candidates compete against male candidates who may have more money to spend on campaigning. Voters, hypothetically, may discriminate against female candidates. Others disagree, pointing out that women have fared well in certain open-list systems (Matland, 2006; Schmidt, 2003; Schmidt and Saunders, 2004).

The effect of gender quotas in electing women to office is also believed to depend on the number of seats in a district. Low district magnitude may disadvantage women because it limits the number of seats that any party may win, for the first one or two seats tend to go to men, not women (Gray, 2003; Htun and Jones, 2002). More recent studies suggest that it is not district magnitude per se, but party magnitude, the ratio of the seats that parties win to the total number of available seats, that influences the effect of quotas on the election of women (Matland, 2006; Schmidt and Saunders, 2004). Other election laws have been found to influence the effect of quotas on the election of women. In Argentina's provincial elections, when parties are allowed to present multiple subparty lists in a district, the effect of quotas on the election of women is lower (Jones, 1998).

Democratization can have contradictory effects on the implementation of gender quotas. In Mexico, attempts to improve democracy resulted in the adoption of a gender quota law and the decentralization of the candidate nomination process through the holding of primary elections. Yet, parties that held primary elections were exempted from enforcing the gender quota law (Baldez, 2007). Independent constitutional courts, ostensibly a democratic institution, can interpret gender quota laws differently. In Italy, for instance, the Constitutional Court struck down the quota law in 1995 (Meier, 2004; Schwindt-Bayer, 2009). In Benin, the adoption of a gender quota law has been stalled in the National Assembly, partly out of fear that the Constitutional Court will reject the gender quota as unconstitutional (unless the law requires parity between men and women). ${ }^{3}$

Crucial for the implementation of gender quotas, according to some scholars, is whether gender quotas fit with formal and informal institutions. Informal institutions include unwritten rules, norms, and discourses about gender, equality, and democracy. Different models of political citizenship (liberal, republican, corporatist, and hybrid) and different discourses about the need for gender quotas can help produce different frames for implementing gender quotas ( Krook et al., 2009; Sgier, 2004). Quotas can combine with existing institutions in a harmonizing sequence that facilitates the implementation of gender quotas (Krook, 2009). Alternatively, quotas can combine with existing institutions in a disjointed sequence, which hinders the implementation of gender quotas.

\section{The agency of actors}

Recently, scholars have called for more attention to the role of actors in making quotas work. Actors "ultimately construct the meanings that are given to quotas as reforms that either fulfill or undermine reigning definitions of equality, representation, and gender" (Krook et al., 2009, p. 783). Such actors include and are not limited to women's activists. In Argentina, women's activists went to the courts to ensure that political parties respected the quota law (Htun \& Jones, 2002, p. 42). Belgium's electoral system uses open lists, and its quota law does not have a placement mandate. Yet, its quota has been effective in the election of women because of the pressure that the women's movement applied on the political parties (Matland, 2006). Women's activists in the Lima province in Peru also helped make the quota effective in the 1998 municipal elections by pressuring party leaders to include more women on their party lists (Schmidt \& Saunders, 2004, p. 727).

Other studies suggest that the agency of political party elites affects the implementation of gender quotas, as parties choose to comply or to find loopholes in the quota law. This may depend on factors such as the party's attitude towards women (Murray, 2004). The way parties respond to gender quotas may also reflect the parties' priorities. If parties prioritize ideological coherence and espouse a gender egalitarian ethic (such as the Green Party in France), then they are likely to fully comply with gender quotas and promote the election of women. For electoral-professional parties (such as the Socialist Party in France), then party leaders will make a cost-benefit analysis in terms of applying the gender quota. For vulnerable parties (such as the UDF in France), they may be less inclined to comply with gender quotas (Murray, 2007). Once committed to "good-faith compliance" (Htun \& Jones, 2002), whether for ideological or strategic reasons or both, parties can voluntarily put in place their own quota rules that exceed what the law demands. For instance, the parallel use of party quotas and legal quotas in Belgium has had a mutual contagion effect, resulting in a significant increase in the election of women 
(Meier, 2004). In other cases, parties install a placement mandate of their own volition. South Korean parties voluntarily use the zipper rule of alternating women and men on their lists (Schwindt-Bayer, 2009, p. 21).

Interestingly, the studies mentioned above examine agency and gender quota laws in democratic contexts. If actors are better able to exercise their agency in democratizing countries, then it follows that the effect of gender quotas on the election of women in democratizing countries is unpredictable. With the increased protection of civil liberties, actors ostensibly have greater opportunities to mobilize for, and against, the implementation of gender quota laws.

\section{Niger's gender quota law}

In May 2000, Niger's democratically elected National Assembly voted in favor of a bill to create a quota system in elected offices, the government, and public administration. The National Assembly, however, modified the bill. The original bill proposed a $25 \%$ gender quota for the election of the legislature and local office. A number of parliamentarians argued that quotas for elected office were undemocratic and would be difficult to enforce. In a compromise measure, the assembly agreed to support the quota if the quota for elected office was lowered to $10 \%$ (Kang, 2013). The following month, on June 7, 2000, President Tandja signed the quota system in law, Loi N 2000-008 (République du Niger, 2000).

Not a country to simply copy what others have done, Niger's gender quota law combines two types of quotas into one. The quota law concerns elections: "During legislative and local elections, candidate lists presented by political parties, party coalitions, and groups of independents must include candidates of both sexes." 4 The quota identifies a minimum proportion of men and women elected to office: "In announcing the final election results, the proportion of elected candidates of either sex must not be less than 10 percent." This may look like a reserved seat quota. In Niger, however, the quota is not thought of as a reserved seat because the quota law is explicitly gender neutral. Reserved seats, in contrast, are carved out specifically for women. The quota law also concerns appointments. The law stipulates, "When members of the cabinet and promotions in senior public service are an- nounced, the proportion of either sex must not be less than 25 percent." 5

Loi N 2000-008 did not specify how the quota would be enforced. To address the issue of enforcement, on February 28, 2001, President Tandja's government passed Décret N 2001-056 on the application of the gender quota law (République du Niger, 2001). It states, "During legislative and local elections, all political parties, party coalitions, and groups of independents must, upon compiling their lists... include candidates of one and the other sex such that upon the proclamation of the final results, the proportion of elected candidates of either sex is 10 percent or more." 6 To further clarify the conditions under which both sexes must be elected, the decree states that if a party wins three or more seats in a district, then it must meet or exceed the $10 \%$ minimum requirement. If the election results violate the gender quota law, then the results can be challenged before the Constitutional Court according to the manner and time provided by the law of that jurisdiction. Violations of the gender quota in appointments can be brought to the Administrative Chamber of the Supreme Court. ${ }^{7}$

\section{The effect of the gender quota law in Niger}

The gender quota law helped increase the number of women in elected offices in the 2000s. As Niger experimented with democracy in the 1990s, the percentage of women in the National Assembly experienced several setbacks. In Niger's first multiparty elections, in 1993, women won five out of 83 seats in parliament. In the 1995 elections, however, three women were elected to parliament. The number further declined to one woman elected in the highly disputed 1996 elections and one woman elected in the relatively free and fair 1999 elections (Hamani, 2001; Maman, 2000). In the first legislative elections to apply the gender quota, the presence of women jumped from $1.2 \%$ in 1999 to $12.4 \%$ in 2004 (Inter-Parliamentary Union, 2012). Fourteen women entered the 113-seat National Assembly. It marked the first time that women's presence in the national legislature passed the $10 \%$ benchmark. In the 2011 legislative elections, 15 women were elected. Table 2 shows the increase of women's descriptive representation over time and breaks down the percentage of women in the national legislature by political party.

Table 2. Women in the unicameral legislature in Niger.

\begin{tabular}{llll}
\hline Political party & $\begin{array}{l}\text { \% Women elected in } 1999 \\
\text { (total seats won) }\end{array}$ & $\begin{array}{l}\text { \% Women elected in 2004 } \\
\text { (total seats won) }\end{array}$ & $\begin{array}{l}\% \text { Women elected in 2011 } \\
\text { (total seats won) }\end{array}$ \\
\hline MNSD & $2.6 \%(38)$ & $17.0 \%(47)$ & $7.7 \%(26)$ \\
CDS & $0.0 \%(17)$ & $13.6 \%(22)$ & $0.0 \%(3)$ \\
PNDS & $0.0 \%(16)$ & $8.0 \%(25)$ & $18.9 \%(37)$ \\
RDP & $0.0 \%(8)$ & $0.0 \%(6)$ & $28.6 \%(7)$ \\
ANDP & $0.0 \%(4)$ & $20.0 \%(5)$ & $12.5 \%(8)$ \\
RSD & - & $0.0 \%(7)$ & - \\
PSDN & - & $0.0 \%(1)$ & - \\
MDN & - & - & $8.0 \%(25)$ \\
UDR & - & - & $16.7 \%(6)$ \\
Total number of women elected & 1 out of 83 & 14 out of 113 & 15 out of 113 \\
Percentage of women in the legislature & $1.2 \%$ & $12.4 \%$ & $13.3 \%$ \\
\hline
\end{tabular}

Sources: Assemblée Nationale du Niger (2012), IPU (2012), and Le Sahel (2011). 
The gender quota law's stipulation on the appointment of women and men also helped facilitate the ascent of women in the executive cabinet in the 2000s, though women's presence in the executive cabinet had been higher than that of the national legislature. Women made up $8.5 \%$ of the cabinet in the first democratically elected government in 1993. In 1999, the figure dropped to 5.2\% in the Fourth Republic. Immediately following the adoption of the gender quota, the minimum $25 \%$ requirement was not met, but since 2005, women have occupied 24.0 or more percent of the cabinet. Women have served as ministers of agriculture, commerce, communication, foreign affairs, labor, national education, public health, small business, social welfare, tourism, and transportation (Center for Intelligence Agency (CIA), 2011; Hamani, 2001).

\section{Quota design}

The effect of Niger's quota law on the election of women can be partially explained by the quota's size, placement mandate, and enforcement mechanisms. Loi N 2000-008 sets a $10 \%$ minimum requirement for the election of women (and men) in legislative elections, which was respected in 2004 and 2011. Décret N 2001-056 establishes a placement mandate, requiring that if a party wins three seats in a district, the party must respect the quota (i.e., at least one member of each sex must be elected from that district). The decree also specifically states that the Constitutional Court can be called upon if the final election results do not satisfy the quota's requirements. This enforcement mechanism helped deter political parties from violating the stipulations of the gender quota law. Parties feared the Constitutional Court's rejection of their lists, for the Court had previously exercised its power to rule over the eligibility of candidates and over contentious matters during the conduct of elections. As one woman who ran in the 2004 elections said:

My candidacy was motivated by the quota law. So as not to see its list rejected by the Constitutional Court, our party asked all of its members with some education and capable of mobilizing people to offer their names. ${ }^{8}$

The quota law did not specify whether a quota should be applied to Niger's special single-member districts or what are known as special constituency seats. These eight single-member districts were originally created to promote the descriptive representation of the least numerous ethnic minorities such as Arabs, Gourmantchés, and Toubous. (The special constituency seats are not seats for Tuaregs, as some suggest, though Tuaregs live in some of the singlemember districts.) By my count, all of the special seats, to which the quota did not apply, have been won by men. ${ }^{9}$

Similarly, the effect of Niger's quota law on the appointment of women in the executive cabinet can be partially explained by the quota's size and enforcement mechanisms. Loi N 2000-008 sets a $25 \%$ minimum requirement for the appointment of women (and men). Décret N 2001-056 specifically states that the administrative division of the Supreme Court can be called upon if the government violates the gender quota. The gender quota in appointments, however, has been inconsistently applied in public administration, particularly in the appointment of high school princi- pals, prefects, and high-level bureaucrats in the Ministry of Defense and Ministry of Interior. This lack of enforcement in the appointment of women has not been heavily scrutinized by the Supreme Court.

\section{Institutional context}

Gender quota laws do not operate in a political vacuum. As mentioned above, institutions, including formal bodies like the Constitutional Court, facilitated the implementation of the gender quota law by raising the costs of non-compliance. One party official told me that the court can block a party's list; if a list has 12 candidates, the official said, there must be 3 women. ${ }^{10}$ This suggests that party officials are to some degree concerned about the Constitutional Court, which has a record of invalidating candidates on party lists for other reasons such as not filing the necessary paperwork or listing the same candidate twice.

Niger's electoral system also affected the quota's implementation. Here, it is important to know that Niger has eight multi-member districts and eight single-member districts. The multi-member districts ranged in size from 5 seats to 21 seats in the 2004 legislative elections. Niger's legislative electoral system, however, is characterized by low party magnitude. That is, parties do not win many seats in a district. For instance, in 2004 in Agadez, which has five seats, three parties won one seat each and MNSD won two seats (Cour Constitutionnelle, 2004). Because none of the parties won three or more seats in Agadez, none of those parties were required to elect both members of the sex to the National Assembly from that district. To give another example, Dosso has 14 seats. In 2004, ANDP won four seats, MNSD won four seats, and three other parties won two seats each. According to the quota law, ANDP and MNSD each needed to send at least one woman and one man to the National Assembly from Dosso, which they did. The other three parties, however, were not required to elect women (or men) to represent Dosso in the National Assembly. Low levels of party magnitude make it difficult to consistently force parties to apply the quota. This inconsistent use of the gender quota law in elections reflects the "win three seats or more" rule and the number of parties competing for a relatively small number of seats.

\section{The agency of actors}

After President Tandja signed the gender quota into law, women's civil society organizations, female politicians, and female bureaucrats mobilized to ensure its implementation. In a multi-pronged approach, women's activists spread awareness about the gender quota law, provided support to female candidates, framed the quota law as legitimate, put pressure on political parties to respect the quota law by using the Constitutional Court, and appealed to international organizations and donors. One of the most active civil society organizations in the mobilization effort was the Confederation of Women's NGOs and Associations of Niger (CONGAFEN, Coordination des Organisations Non Gouvernementales et Associations Féminines Nigérienne). CONGAFGEN was created by women's leaders in 1995 to help bring Niger's women's associations and NGOs together into a larger, collective voice. With 34 mem- 
ber NGOs and associations and growing, CONGAFEN was the largest umbrella of women's organization in Niger throughout the 2000s.

Women's activists in CONGAFEN and their allies worked to spread awareness among Nigériens about the new gender quota law. Along with a network of female ministers and parliamentarians (REFAM/P), CONGAFEN helped organize a conference to publicize the gender quota law in March 2002 (Association des Femmes Juristes du Niger (AFJN), 2005; Alidou and Alidou, 2008; M.Z., 2002, March 7). A West African regional organization, Institute PANOS Afrique de l'Ouest, commissioned newspapers to write about the quota law in 2003 (Abdelkader, 2003). Radio Saraounia FM aired a discussion entitled, "The Women's Quota Law in Niger: Myth or Reality," in January 2004 (AFJN, 2005). The Centre Afrika Obota organized a debate on the participation of women in the electoral process that was televised on the state-sponsored station, ORTN. ${ }^{11}$ Women's activists also organized workshops to encourage women to run for office and lobbied political parties to support female candidates. As a female candidate said, "With the support of the party and some women's organizations, I wasn't afraid to jump into the water" (Institut PANOS, 2005).

Discursively, women's activists called for the election of women as just and fair, particularly because women formed the grassroots base of the major political parties. Women's activists also pointed to the role of women in politics before the advent of democracy. While women were mostly absent from official positions of power during the authoritarian era, women were visible in the public sphere and participated in politics. Nearly all of the top female government officials in the 1990s were state employees in the health, education, media, and banking sectors in the 1970s and 1980s. Maiga Amsou Amadou, the first Director of Niger's Department of the Advancement of Women in 1981, started her career as a nurse (Alzouma, 2009). Said to have escaped an early marriage thanks to the intervention of a school principal, Maiga Amsou's work in public health earned her the prestigious Chevalier de l'Ordre du mérite and Croix d'officier de l'Ordre du mérite. Michèle Claude Hadiza taught junior high in the 1970s and 1980s before advocating for women's rights in the Ministry of Social Development in democratic Niger.

Women also resided in the public sphere as oral historians, renowned songwriters, and praise singers. The lives and output of Niger's female literary artists have begun to be studied by scholars such as Thomas Hale (1994), Aissata Sidikou (2001), and Ousseina Alidou (2005). These scholars bring to life public figures such as Habsu Garba, a bank worker who as a high school student loved learning Qu'ranic verses by song. Over the 1980s, Garba developed a career as a songwriter and praise singer. Garba became an "artistic icon" for the one-party state, greeting foreign presidents with her songs and her large musical troupe (Alidou, 2005; Seydou, 2011b). Moreover, women participated in politics at the community and regional levels by holding customary titles (e.g., magajiya, iya, inna, maidaki) and volunteering with the Association of Nigérien Women (AFN) to name just two paths of political influence (Cooper, 1997; Seydou, 2011b). Women were absent among the official, national elite during the authoritarian-military era, but they were not absent from politics.
In addition to organizing consciousness-raising activities, supporting female candidates, and framing the quota as legitimate, women's activists publicly called upon the Constitutional Court to invalidate party lists that violated the gender quota law. The intent was to put pressure on political parties. This call occurred shortly before the Constitutional Court announced the results of the 2004 local elections. ${ }^{12}$ Recall that the quota mandates that parties must have women and men on their lists and that a minimum $10 \%$ of winners must be of one or the other sex. The law, however, does not specify how many women are required to be on a party-list, whether a woman and a man must be on each list for every region, or how the $10 \%$ minimum would be met. Women's activists worried that political parties would use the vagueness of the law to favor male candidates and not give enough seats to women to meet the $10 \%$ minimum requirement. Out of this concern, women's activists from CONGAFEN, its member organizations, and women active in political parties came together and released a press statement through the state radio and television station, asking the Constitutional Court to ensure that the quota law be respected. According to different interviewees, the Constitutional Court did invalidate party lists that did not respect the gender quota law, though I have not found evidence of this in the existing archives of the Constitutional Court.

To further support the implementation of the quota in Niger, women's activists spoke to international audiences about the gender quota. In 2007, women's activists from CONGAFEN, ONG Dimol, SOS FEVVF, AFJN, AN$\mathrm{DDH}$ and other organizations submitted a report to the United Nations Committee on the Elimination of Discrimination Against Women. In the report, the organizations complained that "the quota law is not respected." The civil society organizations called for the quota's effective application. ${ }^{13}$ Women's activists used UN reporting mechanisms, contacts inside the government, and, in a democratic context, the media to call the government out on its non-respect of the gender quota.

CONGAFEN and other groups applied for funding from international development organizations to support their advocacy. CONGAFEN at the time was partially supported by Canadian donors such as the Canadian International Development Agency and Oxfam-Quebec, among other development organizations (CONGAFEN, 2005). The Canadian agency later provided funding to CONGAFEN in 2007 to help train women to participate in politics (CIDA, 2013). Other organizations also provided financial support to women's civil society organizations for the promotion of women's political participation, such as the American-based National Democratic Institute (NDI), the Netherlands Development Organization (SNV), and the United Nations Population Fund (UNFPA).

When it came to the quota's provision on cabinet appointments, women's activists focused their efforts on monitoring and public shaming. Activists released public declarations via the public and private media stations to shame the government when it did not follow the gender quota law. In 2004, for instance, before the announcement of the members of the new executive cabinet, CONGAFEN released a statement calling upon the president, the prime minister, and the heads of political parties to implement the gender quota and appoint a sufficient number 
of women to the new cabinet, noting that the previous government did not implement the quota law (PANA, 2004). ${ }^{14}$ According to one journalist, who was also a women's activist, this strategy was used multiple times. ${ }^{15}$ The following transcript of a meeting with former presidents of CONGAFEN illustrates in more detail the logic behind these declarations: ${ }^{16}$

Fourth President of CONGAFEN: The government, someone called me to say that the government would be composed of only six women. Isn't that right?

Someone in the room: $\mathrm{Mmm}, \mathrm{hmm}$.

Fourth President: I called my staff. I said that the government might take six women. The quota law wouldn't be respected. So we released a declaration. What we did, it was a threat and the quota was put into effect.

CONGAFEN staff person: Even yesterday, we proposed to make a declaration.

Fourth President: When I went to see [a contact in the government] he told me tanti, good thing you all released the statement because they had intended to put six women instead of eight. And when we took the photo de famille, the president said [to the women ministers], 'You bring yourselves forward, because I learned that CONGAFEN is making complaints. Stand in front for CONGAFEN to see that there are eight women.' At all times, we must question them.

First President of CONGAFEN: Absolutely.

As activists called for the application of the gender quota law, ministers themselves began to monitor the implementation of the quota law. As a former minister of agriculture and animal husbandry explained in an interview:

When the cabinet met to review new appointments, we'd count the number of women and men being nominated for promotion. [With his finger, he motions going down an imaginary list.] If women weren't on the list of names, we'd send it back to the minister. The female ministers were vigilant about this. The women were the most vigilant, but the men would count, too. ${ }^{17}$

Former ministers volunteered that, in particular, the Minister of Social Development reminded the cabinet to look for women in the new appointments during cabinet meetings with the president. One former minister said that the cabinet was inspecting the balance of men and women on February 19, 2011, the day President Tandja's government was toppled by a military coup:

The day Tandja was overthrown, we were at a cabinet meeting in his office. Everyone in the room was counting the number of women on a list. Even Tandja himself. Then, I swear, that's when we heard gunshots, and the tanks came in. Pop pop pop! [Imitating the sound of gunfire.] ${ }^{18}$
Why was President Tandja, in what would be one of his last moments in office, fastidiously tallying up women's presence in public life? The government's attention to women's representation can be traced back to women's mobilization in and outside the state for the implementation of the gender quota.

Activists and government officials have begun to shift their focus from cabinet posts to other positions in the government. In 2011, activists complained that out of 50 advisors to the president, only three were women. I also heard complaints that there were not a sufficient number of female teachers being promoted to high school principals, and that out of 20 executive directors of parastatal companies, only three were women..$^{19}$ Others are concerned with the lack of female prefects outside the capital of Niamey. One issue that I heard was that prefects lead or take part in the prayer that precedes a religious holiday, and that this role is usually played by a man, not a woman. ${ }^{20} \mathrm{~A}$ sociologist conducted a study on the application of the quota in Niger, which found that the application of the quota was weakest in the Ministry of Defense and Ministry of the Interior. Women's activists presented the study to Mahamadou Issoufou on the day of his presidential inauguration in 2011. ${ }^{21}$

By the end of the 2000s, high-ranking government officials were keeping track of women's representation in government offices as if it were the normal thing to do. Consider Niger's electoral commission (Commission Electorale Nationale Indépendante, CENI). Up until the gender quota law, the CENI was not required to have women on its commission. Following the adoption of the gender quota, the government required that the CENI include a representative from an umbrella women's association and a representative of the government office on the advancement of women. Consider also the High Council on Communication (Conseil Supérieur de la Communication, CSC). In the 2011 Constitution, Article 161 stipulates that out of 15 members of the Council, there must be at least three women (one representing private media, one representing public media, and one representative elected by women's umbrella associations) (République du Niger, 2011, Titre VIII, Article 161).22

\section{Discussion and Conclusion}

This article has suggested that the gender quota's effect on the election and appointment of women can be traced to a combination of three factors. The design of the quota law mattered. The quota's $10 \%$ minimum requirement for elected office and $25 \%$ minimum requirement for appointments, the placement mandate, and the establishment of an enforcement mechanism help explain why women's election to the legislature and appointment to the cabinet has reached or exceeded 10 and $25 \%$, respectively. Second, the Constitutional Court had the power to invalidate party lists, but low party magnitude exempts parties that win two or fewer seats from applying the gender quota. Third, women's activists in and outside political parties mobilized to ensure that the Constitutional Court monitored party lists and the election results. To promote the quota as legitimate, women's activists argued for the appropriateness of women's participation in public life. Women's activists and supporters inside the ministries helped implement the quota in the cabinet and public administration. This con- 
certed mobilization helped normalize and mainstream the inclusion of women in politics in Niger.

Gains in the national legislature aside, important criticisms have been raised about the gender quota. One criticism is that the quota helps elect so-called elite women and does not assist female domestic servants, market women, or women farmers into public office (Alidou \& Alidou, 2008). A similar point can be made, however, for male MPs, who primarily are former state employees, chiefs, or wealthy merchant-traders (Maman, 2000). Democratic representation, however, may not be truly democratic if people of lower socioeconomic standing are systematically excluded from holding office.

Thus far, political parties have interpreted the quota's minimum requirement as a threshold to meet, rather than a level to exceed. This has made the quota law act like a reserved seat system; the quota appears to becoming a "new glass ceiling" for women (Dahlerup, 2009, p. 35 . Women's activists have lamented that female candidates struggle to win seats beyond the minimum required number partly due to the amount of money needed to run for office in democratic Niger. Other activists argue that women are marginalized in political parties. "Some notable gains have been made," said Niger's first female minister, Aissatou Moumouni, in a 2011 interview with Aicha, "but on the quota law, within political parties, especially in the top positions, are women sufficiently represented? That is the real question!" (Seydou, 2011a). Recognizing the challenges that women candidates face within their own parties, activists have lobbied for a revised quota law that raises the minimum bar. During a visit to Niamey in 2011, women's activists told me that they were seeking a 25,30 , or $50 \%$ quota, but that they did not agree on a set percentage. The government, led by the socialist-leaning party, PNDS, currently does not appear committed to revising the quota law.

In conclusion, the relationship between democratization and gender quota laws is multifaceted and dynamic. Disappointment in the low numbers of women elected in new African democracies helped inspire the push for gender quotas. The democratically elected National Assembly, however, lowered the proposed gender quota for elections from 25 to $10 \%$ in Niger. To implement gender quota laws, activists made use of their civil liberties by going to the media outlets and appealed to the independent Constitutional Court. The way competitive elections have been structured in Niger, with five or more parties winning seats in a district, limit the application of the gender quota law. Identifying the relationships between design, existing institutions, and activism is important to advancing women's representation.

Acknowledgments - The fieldwork on which this article is based was funded by the U.S. Department of State's Fulbright Hays Doctoral Dissertation Research Award and a Senning Fellowship from the Department of Political Science at the University of NebraskaLincoln. I thank the Idrissa Yansambou and the excellent staff of the National Archives of Niger, Gender in Social Science Writing Group at the University of Wisconsin-Madison, the Human Rights and Humanitarian Affairs faculty brown-bag at the University of NebraskaLincoln, Soumana Cissé, Nouhou Moussa, and Alex Kroeger for their time and help. All remaining faults and omissions are the author's own

\section{Notes}

1. I use the terms new democracy and democratizing country interchangeably. Democratization refers to a process of adopting practices that promote electoral competition and the inclusion of all members of society.

2. Measures of democracy vary. Polity IV categorizes Niger as a democracy (8 on the Polity scale) in the early 1990s. Following coup d'états in 1996 and 1999, Niger's ranking on the Polity scale fell. After the 1999 coup, Polity IV recategorized Niger as a democracy (5 or 6 on the Polity scale) until President Tandja dissolved the Constitutional Court in 2010. Freedom House categorizes Niger as partly free.

3. Interview with a female judge, Cotonou, Benin, June 4, 2008. See also Quotidien Nokoué (2004). Translations from French are by the author.

4. République du Niger, Loi N 2000-008 du 07 juin 2000, Article 3.

5. République du Niger, Loi N 2000-008 du 07 juin 2000, Article 4.

6. République du Niger, Décret N 2001-056/PRN/MDSP/PF/PE, Article 2.

7. République du Niger, Décret N 2001-056/PRN/MDSP/PF/PE, Articles 3,4 , and 6 .

8. As quoted in Institut PANOS (2005).

9. The special constituencies are Bilma, Banibangou, Bankilaré, Bermo, N'Gourti, Tassara, Terker, and Torodi (Cour Constitutionnelle, 2004).

10. Interview with a party official of RSD-Gaskiya, Niamey, Niger, June 11, 2011.

11. The name of the video is "Participation des femmes au processus electoral," which I watched at CAO's headquarters in Niamey in 2008.

12.Interview with a former president of CONGAFEN, Niamey, Niger, May 22, 2008 and December 27, 2012.

13. See the "CONGAFEN (2007), pp. 34-35".

14. The declaration noted that the previous government had four female ministers out of 24 , or $16.7 \%$.

15. Interview, Niamey, Niger, January 3, 2013.

16. Group meeting at CONGAFEN, Niamey, Niger, June 30, 2011.

17. Interview with a former Minister of Agriculture and Animal Husbandry, Niamey, Niger, June 14, 2011.

18. Interview with a former Minister of Social Development, Niamey, Niger, June 30, 2011.

19. Fieldnotes, June 2011 and Le Républicain (2003).

20. I heard an anecdote that a woman was once nominated to be prefect of Bouza, but "the population refused".

21. Personal communication with a member of ANDDH, June 24, 2011.

22. Note that the assistant rapporteur to the Conseil Constitutionnel National was a woman. The Constitution also called for the "equal representation in public institutions through a national policy and the respect of quotas" (Titre II, Article 22), but it does not call for a specific percentage or mode of application.

\section{References}

Abdelkader, Aghali (2003,March 27). Le quota des femmes dans l'administration publique et les partis politiques (pp. 4). Le Republicain.

Alidou, Ousseina (2005). Engaging modernity: Muslim women and the politics of agency in postcolonial Niger. Madison: University of Wisconsin Press.

Alidou, Ousseina, \& Alidou, Hassana (2008). Women, religion, and the discourses of legal ideology in Niger Republic. Africa Today, 54(3), 21-36.

Alzouma, Mariama (2009). Maiga Amsou: Une femme de combat. Aicha, 11,6 .

Assemblée Nationale du Niger (2012). Groupes parlementaires; http:// www.assemblee.ne accessed February 10, 2013.

Association des Femmes Juristes du Niger (AFJN) (2005). Rapport d'activités. Niger: Niamey.

Baldez, Lisa (2004). Elected bodies: The gender quota law for legislative candidates in Mexico. Legislative Studies Quarterly, 24(2), 231-258.

Baldez, Lisa (2007). Primaries vs. quotas: Gender and candidate nominations in Mexico, 2003. Latin American Politics \& Society, 49(3), 69-96.

Ballington, Julie (Ed.). (2004). The implementation of quotas: African experiences. Stockholm: International IDEA. 
Bauer, Gretchen, \& Britton, Hannah (2006). Women in African parliaments. Boulder: Lynne Rienner.

Burnet, Jennie (2008). Gender balance and the meanings of women in governance in post-genocide Rwanda. African Affairs, 107(428), 361-386.

Burnet, Jennie (2011). Women have found respect: Gender quotas, symbolic representation, and female empowerment in Rwanda. Politics $\mathcal{E}$ Gender, 7(3), 303-334.

Canadian International Development Agency (CIDA) (2013). Disclosure of grant and contribution awards over $\$ 25,000$. http://www.acdicida.gc.ca/ accessed February 2, 2013.

Center for Intelligence Agency (CIA) (2011). Chiefs of state and cabinet members of foreign governments: A directory. (Washington, D.C.).

Cheibub, José Antonio, Gandhi, Jennifer, \& Vreeland, James Raymond (2010). Democracy and dictatorship revisited. Public Choice, 143(2-1), 67-101.

CONGAFEN (2005). Rapport d'activités de la CONGAFEN. Niger: Niamey. CONGAFEN (2007). English executive summary of Nigerien NGO report on the status of CEDAW. http:/ / www.iwraw-ap.org/

Cooper, Barbara (1997). Marriage in Maradi: Gender and culture in a Hausa society in Niger. Portsmouth: Heinemann.

Cour Constitutionnelle (2004). Arrêt N 2004-53/04/CC/ME du 01 novembre 2004.

Dahlerup, Drude (Ed.). (2006). Women, quotas, and politics. New York: Routledge.

Dahlerup, Drude (2009). Women in Arab parliaments: Can gender quotas contribute to democratization? Al-Raida, 126-7, 28-38

Dahlerup, Drude, \& Freidenvall, Lenita (2005). Quotas as a 'fast track' to equal representation for women. International Feminist Journal of Politics, 7(1), 26-48.

Dahlerup, Drude, \& Freidenvall, Lenita (2011). Electoral gender quota systems and their implementation in Europe. Brussels: European Parliament.

Goetz, Anne Marie (2003). The problem with patronage: Constraints on women's political effectiveness in Uganda. In Anne Marie Goetz, \& Shireen Hassim (eds.), No shortcuts to power: Women in politics and policy making (pp. 110-139). London: Zed Books.

Gray, Tricia (2003). Electoral gender quotas: Lessons from Argentina and Chile. Bulletin of Latin American Research, 22(1), 52-78.

Hale, Thomas (1994). Griottes: Female voices from West Africa. Research in African Literatures, 25(3), 71-91.

Hamani, Abdou (2001). Les femmes et la politique au Niger. Paris: L'Harmattan.

Hassim, Shireen (2010). Perverse consequences? The impact of quotas for women on democratization in Africa. In Ian Shapiro, Susan Stokes, Elisabeth Jean Wood, \& Alexander Kirshner (eds.), Political representation (pp. 211-235). Cambridge: Cambridge University Press.

Howard-Merriam, Kathleen (1990). Guaranteed seats for political representation of women: The Egyptian example. Women and Politics, 10(1), $17-42$.

Htun, Mala, \& Jones, Mark (2002). Engendering the right to participate in decision-making: Electoral quotas and women's leadership in Latin America. In Nikki Craske, \& Maxine Molyneux (eds.), Gender and the politics of rights and democracy in Latin America (pp. 32-56). New York: Palgrave.

Institut PANOS (2005). Le piège du quota se referme sur les femmes. http://www.panos-ao.org/ipao/spip.php?article3491\# accessed May 10, 2009.

International IDEA (2010). Global database of quotas for women. http:// www.quotaproject.org/ accessed February 11, 2013.

Inter-Parliamentary Union (2012). Niger: Last elections. http://www. ipu.org/parline-e/reports/2237 E.htm accessed June 30, 2012.

Jones, Mark (1996). Increasing women's representation via gender quotas: The Argentine Ley de Cupos. Women E Politics, 16(4), 75-98.

Jones, Mark (1998). Gender quotas, electoral laws, and the election of women: Lessons from the Argentine provinces. Comparative Political Studies, 31(1), 3-21.

Jones, Mark (2004). Quota legislation and the election of women: Learning from the Costa Rican experience. Journal of Politics, 66(4), 1203-1223.

Jones, Mark (2009). Gender quotas, electoral laws, and the election of women: Evidence from the Latin American vanguard. Comparative Political Studies, 42(1), 56-81.

Jones, Mark, \& Navia, Patricio (1999). Assessing the effectiveness of gender quotas in open-list proportional representation electoral systems. Social Science Quarterly, 80(2), 341-355.

Kang, Alice (2013). Bargaining for women's rights: Gender, religion, and politics in Niger. (Manuscript).

Krook, Mona Lena (2008). Quota laws for women in politics: Implications for feminist practice. Social Politics: International Studies in Gender, State and Society, 15(3), 345-368.
Krook, Mona Lena (2009). Quotas for women in politics: Gender and candidate selection reform worldwide. Oxford: Oxford University Press.

Krook, Mona Lena, Lovenduski, Joni, \& Squires, Judith (2009). Gender quotas and models of political citizenship. British Journal of Political Science, 39(4), 781-803.

Le Sahel (2011, January 17). Résultats.

Longman, Timothy (2006). Rwanda: Achieving equality or serving and authoritarian state? In Gretchen Bauer, \& Hannah Britton (Eds.) Women in African parliaments (pp. 133-150). Boulder: Lynne Rienner.

M.Z. (2002, March 7). Le système de quota et son décret d'application: De la théorie à la pratique (pp. 4). Le Démocrate.

Maman, Chaïbou (2000). Répertoire biographique des personnalités de la classe politique, 2, Niamey: Editions Démocrates.

Matland, Richard (2006). Electoral quotas: Frequency and effectiveness. In Drude Dahlerup (Ed.), Women, quotas, and politics (pp. 275-292) New York: Routledge.

Meier, Petra (2004). The mutual contagion effect of legal and party quotas: A Belgian perspective. Party Politics, 10(5), 583-600.

Miguel, Luis (2008). Political representation and gender in Brazil: Quotas for women and their impact. Bulletin of Latin American Research, 27(2), $197-214$.

Muriaas, Ragnhild, \& Wang, Vibeke (2012). Executive dominance and the politics of quota representation in Uganda. The Journal of Modern African Studies, 50(2), 309-338.

Murray, Rainbow (2004). Why didn't parity work? A closer examination of the 2002 election results. French Politics, 2(3), 347-362.

Murray, Rainbow (2007). How parties evaluate candidate quotas: A study of the implementation of the 'parity' law in France. Parliamentary Affairs, 60(4), 368-384.

Murray, Rainbow (2010). Parties, gender quotas, and candidate selection in France. New York: Palgrave.

Murray, Rainbow (2013). Towards parity democracy? Gender in the 2012 French legislative elections. Parliamentary Affairs, 66(1), 197-212.

Pan-African News Agency (PANA) (2004, December 26). Les femmes réclament plus de place aux emplois supérieurs. http://www.panapress.com/Les-femmes-reclament-plus-de-place-aux-emplois-superieurs-12-728563-10-lang4-index.html accessed September 12, 2012.

Quotidien Nokoué (2004, October 9). Minorité féminine à l'assemblée nationale: L'honorable Justine Achadé propose le quota de $50 \%$ (pp. 3).

République du Niger (2000). Loi N 2000-008 du 7 juin 2000, instituant le système de quota dans les fonctions électives, au Gouvernement et dans l'administration de l'État.

République du Niger (2001). Décret N 2001-056/PRN/MDSP/PF/PE du 28 février 2001 portant modalités d'application de la Loi N 2000-008 du 7 juin 2000 instituant le système de quota.

République du Niger (2011). Constitution de la VII République.

Schmidt, Gregory (2003). Unanticipated successes: Lessons from Peru's experienceswith gender quotas inmajoritarian closed list and open list PR systems. Paper presented at the international IDEA workshop. Peru: Lima.

Schmidt, Gregory, \& Saunders, Kyle (2004). Effective quotas, relative party magnitude, and the success of female candidates: Peruvian municipal elections in comparative perspective. Comparative Political Studies, 37(6), 704-724.

Schwindt-Bayer (2009). Making quotas work: The effect of gender quota laws on the election of women. Legislative Studies Quarterly, 34(1), $5-28$.

Seydou, Assane (2011a). Moumouni Aïssata: Une vie consacrée à l'enseignement. Aicha, 20, 5.

Seydou, Assane (2011b). Habsou Garba continue à donner de la voix. Aicha, 21, 3 .

Sgier, Lea (2004). Discourses of gender quotas. European Political Science, $3,67-72$.

Sidikou, Aissata (2001). Recreating words, shaping worlds: The verbal art of women from Niger, Mali, and Senegal. Trenton: Africa World Press.

Tønnessen Liv, \& Al Naggar, Samia (2013). The women's quoate in conflict ridden Sudan: Ideological battles for and against gender equality. Women's Studies International Forum 41(2), 122-131.

Tripp, Aili Mari, Casimiro, Isabel, Kwesiga, Joy, \& Mungwa, Alice (2009). African women's movements: Transforming political landscapes. Cambridge: Cambridge University Press.

Wang, Vibeke (2013). Women changing policy outcomes: Learning from pro-women legislation in the Ygandan Parliament. Women's Studies International Forum 41(2), 113-121

Yoon, Mi Yung (2013). Special seats for women in parliament and democratization: The case of Tanzania. Women's Studies International Forum 41(2), 133-149.

Yoon,Mi Yung (2001). Democratization andwomen's legislative representation in sub-Saharan Africa. Democratization, 8(2), 169-190. 